УДК 323:351.746.1(477)

https://doi.org/10.34142/24130060.2019.19.2.07

\title{
КАТЕГОРІАЛЬНЕ ВИЗНАЧЕННЯ ПОНЯТТЯ «НАЦІОНАЛЬНІ ІНТЕРЕСИ» У КОНТЕКСТІ НАЦІОНАЛЬНОЇ БЕЗПЕКИ УКРАЇНИ
}

\author{
O.А. Матета \\ Кременчуцький льотний коледж Харківського національного університету внутрішніх \\ справ
}

У статті розглянуто проблему категоріального визначення поняття «національні інтереси» у контексті національної безпеки України. Проаналізовано сутність даної категорії у зарубіжній та вітчизняній науковій літературі, а також у законодавстві України. Визначено власне розуміння поняття «національні інтереси». Висловлено припущення щзодо найоптимальнішої суб 'єктності національних інтересів, а саме - наџія - громадянське суспільство - держава.

Ключові слова: начіональні інтереси, начія, громадянське суспільство, держава, національна безпека, ідентичність, маргінальність.

\section{КАТЕГОРИАЛЬНОЕ ОПРЕДЕЛЕНИЕ ПОНЯТИЯ «НАЦИОНАЛЬНЫЕ ИНТЕРЕСЫ» В КОНТЕКСТЕ НАЦИОНАЛЬНОЙ БЕЗОПАСНОСТИ УКРАИНЫ}

\begin{abstract}
А.A. Матета
В статье рассмотрена проблема категориального определения понятия «национальные интересы» в контексте национальной безопасности Украины. Проанализировано сущность данной категории в зарубежной и отечественной научной литературе, а также в законодательстве Украины. Определено собственное понимание понятия «национальные интересы». Высказано предположение касательно оптимальной субъектности национальных интересов, а именно - нация - гражданское общество государство.
\end{abstract}

Ключевые слова: национальные интересы, нация, гражданское общество, государство, национальная безопасность, идентичность, маргинальность.

\section{CATEGORIAL DEFINITION OF THE NATIONAL INTEREST CONCEPT IN THE CONTEXT OF NATIONAL SECURITY OF UKRAINE}

\begin{abstract}
A. Mateta
The article deals with the problem of categorical definition of the concept of «national interests» in the context of national security of Ukraine. The essence of this category in foreign and domestic scientific literature, as well as in the legislation of Ukraine is analyzed.

It is noted that in foreign literature the concept of "national interests» is in fact associated with the geopolitical interests of the state, the representation of the interests of the nation at the international level. This state of affairs is a consequence of the formation in these countries of nations, civil societies, rule of law.
\end{abstract}

(C) O.А. Матета, 2019 
In Ukraine, which has virtually no tradition of developing its own statehood for centuries, the category of national interests has a different meaning. In particular, their essence is largely determined, in our time, by the need to improve the process of state formation, consolidation of statehood, its self-preservation, formation of the Ukrainian nation, patriotic education of citizens.

It is suggested, under the category of «national interests», to understand the set of common interests and needs common to the nation, the satisfaction and protection of which is a prerequisite for its existence as a subject of history.

It is in the national interest to express the need for a nation to occupy a place in the world community that fully meets its cultural, historical, and spiritual traditions, and that maximizes its potential. And under the term «Ukrainian nation»-both representatives of the Ukrainian ethnic group and national minorities who are citizens of Ukraine.

The article also assumes the most optimal subjectivity of national interests, namely: nation - civil society - state.

The author concludes that under the conditions of the transitional state of our country, where many aspects of political and economic transformation remain unresolved, national interests should become a fundamental basis for Ukraine's national security.

The national interests of Ukraine, as a basis for the safe existence of our state, should not only be proclaimed in political programs, but also enshrined in national legislation, be correlated with the legal values of a democratic society.

Key words: national interests, nation, civil society, state, national security, identity, marginality.

Постановка проблеми. Національна безпека будь-якої держави повинна базуватися, перш за все, на національних інтересах. Взаємозв'язок між проблемою визначення й реалізації національних інтересів і проблемою забезпечення національної безпеки країни визначає характер внутрішньої і зовнішньої політики держави, стратегію їі діяльності як всередині країни, так і на міжнародній арені.

Очевидним є той факт, що сьогодні значно актуалізувалась проблема своєчасного i точного визначення національних інтересів, загроз, що перешкоджають їх досягненню. Це зумовлено не тільки широкомасштабними завданнями державного будівництва (що характерно молодим державам, як наприклад, Україні), а й загальними тенденціями кардинальних змін геополітичного та геоекономічного характеру.

Визначення національних інтересів, їх класифікація, а отже і розробка стратегії, спрямованої на їх досягнення, перетворилося в ще більш складну і суперечливу проблему, ніж у минулому, ще й тому, що значно активізувалися у глобальному масштабі непритаманні раніше загрози міжнародній стабільності та національній безпеці. Передусім, це тероризм, 
різноманітні форми войовничого сепаратизму (ті види сепаратизму, головною метою яких $є$ безумовне відокремлення, а отже, i руйнація територіальної цілісності держави), глобальні проблеми безпеки (особливо екологічна, енергетична та інформаційна), поява та нарощування могутності нових міжнародних центрів економічної, політичної та воєнної сили; намагання деяких країн освоїти технології виробництва та стати володарями зброї масового знищення (ураження), суперечності ціннісного характеру в їх загальноцивілізаційному вимірі (визначені С. Хантінгтоном як «зіткнення цивілізацій»), організована злочинність та ін. (Ситник, 2010, с. 146-147).

Невизначеність національних інтересів має згубні наслідки особливо для молодих держав, позбавляючи їх орієнтирів на майбутнє. У такому становищі опинилась Україна, яка відновилася як незалежна держава на руїнах СРСР. Причому нерідко нова політична сила, яка ставала до владного керма, виступала не як наступник, а як опонент попередньої політики через протилежне тлумачення національних інтересів.

Різноманітні зміни у соціально-політичній структурі України 3 90-х років ХХ століття відбувалися без визначення вектору розвитку, який би грунтувався на національних інтересах. Іншими словами ми змінювалися без напряму, без усвідомлення чого ми хочемо. Тому зараз досить важко визначити яким є українське суспільство. Дослідники його називають по різному: «суспільство 3 подвійною інституціональною системою», «суспільство масової аномійної деморалізації і аморальної більшості», «суспільство 3 цінностями часів викривленого модерну», «суспільство персоніфікованої довіри 3 переважно негативним соціальним капіталом», «суспільство переважно негативних ідентичностей» (Головаха, 2016). Всі ці моделі недобудови, пристосуванства політиків, дезорієнтують населення, підвищують рівень його недовіри до влади. У підсумку ми отримали пострадянське суспільство, яке повільно трансформується, а виклики, що стоять перед ним є занадто небезпечними (Матета, 2018, с. 88). 
Аналіз актуальних досліджень. Слід зазначити, що суспільна категорія «національний інтерес» вже 3 XIX ст. входить до числа базових наукових категорій у Західній Європі і США. Вона активно досліджувалася та аналізується, зокрема, у працях Р. Арона, Ч. Бирда, В. Вільсона, Р. Даля, Ж.-Б. Дюрозеля, У. Липпмана, Г. Моргентау, Р. Нибура, Дж. Розенау, Е. Фернисса та ін.

Метою даної статті є дослідження категорії «національні інтереси» як складової національної безпеки у науковій літературі та законотворчій практиці.

Виклад основного матеріалу. Для кращого розуміння сутності понять «інтерес» і «національний інтерес» у рамках нашого дослідження, вважаємо за потрібне розглянути еволюцію цих категорій у межах теорії влади, оскільки саме в ній, були закладені основи сучасних розумінь, які політологія та геополітика вкладає в поняття «національний інтерес».

Виклад основного матеріалу. Засновником такої традиції можна вважати Р. Даля, що запропонував загальновідому «формулу» влади як здатність А примусити Б робити те, що Б не став би робити. Даль має на увазі негативну направленість волі суб'єкта, який здійснює владу проти інтересів об’єкта. Влада зображується як відкритий конфлікт між інтересами суб'єкта й об’єкта, що виникають у процесі прийняття рішень. Для Р. Даля (1992, с. 70-71) інтерес тотожний заявленій політичній позиції.

Найбільший внесок у вчення про національні інтереси, в рамках теорії влади, зробив німецький вчений Г. Моргентау, який $є$ представником реалістичного підходу до тлумачення національного інтересу. За Г. Моргентау, національний інтерес - це універсальний закон зовнішньої політики держав, тому моральною є лише та політика, яка слідує вимогам національного інтересу, як закон всесвітнього тяжіння - універсальним законам природи. Національний інтерес він розглядає як основну категорію політичного реалізму, і саме з інтересу виводить сутність та цілі політики. «Але тип інтересу, що визначає політичні дії в конкретний історичний 
період, залежить від політичного й культурного контексту, в межах якого формується зовнішня політика» - стверджував Г. Моргентау (1982, р. 320). Також він зазначає, що основним критерієм правильності зовнішньої політики є захист державою національних інтересів. I дані інтереси він розглядає крізь призму політичної влади - влада та інтерес нерозривні явища, й саме в цьому виражається специфіка політичної та зовнішньополітичної cфep.

Інший представник школи реалізму Дж. Кеннан обгрунтовує теорію про відносність морального критерію. Моральні принципи різних режимів можуть бути абсолютно протилежними, i тому неприйнятними один для одного, тому єдиним критерієм, на основі якого може існувати міжнародна система, є критерій «національного інтересу» (2002, с. 348).

Протилежний, ідеалістичний, підхід пропонує В. Вільсон. Він вважав, що під час прийняття рішень політичні діячі мають виходити не 3 політичних, а з моральних принципів. Визначення зовнішньої політики в термінах національного інтересу є дуже небезпечним. Фактично, існують дві зовнішні політики: заснована на національному інтересі та базована на моралі. Дія на основі національного інтересу є аморальною. Політика, яка грунтується на національних інтересах, не враховує громадської думки країни, оскільки не враховує моральних установок і цінностей, які люди виражають під час соціологічних опитувань (Wilson, 1970, p. 234).

Американський вчений Н. Спайкмен розглядав національні інтереси як критерій геополітичної могутності - чим могутніша держава, тим важливіше iii національні інтереси. За Н. Спайкменом, держава має або вступати у геостратегічний союз з іншою державою (державами), якщо результат оцінки iii геополітичних можливостей низький, втрачаючи при цьому частково чи повністю суверенітет та поступаючись національними інтересами, або визначає свої пріоритети і стратегічні позиції самостійно, якщо вона має високий сумарний результат своїх геополітичних можливостей (Москальова, 2016, c. 30). 
Французький дослідник Р. Арон мав схожі погляди на сутність національних інтересів. Він вважав, що інтерес є поняттям занадто загальним і неоднозначним, він відіграє радше ідеологічну та пропагандистську роль у суспільстві, але користуватись ним операційно практично неможливо. Тому діяльність держав у міжнародному середовищі пов'язана не 3 занадто абстрактними та нечіткими інтересами, а 3 цілями, які Р. Арон зводить до вираженої у загальній формі тріади «безпека - могутність - слава». В спрощеній формі йдеться про прагнення держав розширити простір, збільшити кількість підвладних їм людей, поширити ідеологію та цінності, які є для них визначальними. У зовнішній політиці держави політичні особи керуються цими цілями, але в певних конкретних акціях величезну роль відіграють їхні особисті мотиви, які традиційно виправдовуються національними інтересами (Арон, 2000, с. 67).

Отже, аналіз сутності категорії «національний інтерес», у межах теорії влади, в країнах Західної Свропи та США, дозволяє визначити, що дана категорія є досить абстрактною i суб'єктивною, оскільки ऑï параметри визначаються картиною світу і ціннісною системою, яка притаманна певному суспільству i державі. Водночас поняття національних інтересів у цих країнах, стає все більш тотожним з державними інтересами.

Змістовне усвідомлення категорії «національні інтереси» в Україні розпочалося лише з 90-х років XX ст., після розпаду СРСР. Довгий час маючи колоніальне чи напівколоніальне становище український народ не асоціював себе 3 власною державою. У період імперської належності українці постійно зазнавали полонізації, мадяризації, румунізації, русифікації та інших національно-культурних геноцидів. В СРСР, куди не за своєю волею потрапили українці, на перше місце в національній політиці ставили форсоване формування так званого «єдиного радянського народу» на російській традиційній основі при розмиванні єдності не лише населення союзної республіки, а й титульного етносу. Цілеспрямоване «перемішування» населення призвело до посилення відмінностей між 
регіонами і навіть між містом і селом. Якщо в селах зберігалася мова автохтонного населення, то в містах нав’язували російську мову.

Наслідком цих процесів стало таке негативне явище як амбівалентна національна ідентичність. Так у книзі «Зіткнення цивілізацій» С. Хантінгтон, аналізуючи геополітичну ситуацію в світі після розпаду соціалістичного табору, писав про Україну: «Україна є розщепленою країною з двома різними культурами» (Huntington, 1996, p. 165). Мова йде про західну і східну Україну, які, на його думку, радикально відрізняються історією, мовою і релігією. Для підтвердження своїх висновків С. Хантінгтон звертається до результатів президентських виборів 1994 року, коли західна Україна голосувала переважно за Л. Кравчука, а східна - за Л. Кучму, який набрав $52 \%$ голосів. Це не стільки етнічна поляризація, робить висновок С. Хантінгтон, скільки різність у культурах. Споріднену думку висловлює А. Вільсон, представник Лондонської школи славістики і східно-європейских студій. Він пише: «не дивлячись на здобуття незалежності в 1991 році, Україна залишається аморфним суспільством із слабким почуттям національної ідентичності». Основною причиною цього А. Вільсон бачить багаточисельні проекти ідентичності, i неправдивість будівництва цих проектів у минулому. Найбільш важливою відмінною рисою України англійський аналітик вважає реально існуючу серединну основу (middle ground) між українською і російською ідентичностями, яка виявляє великий спротив логіці державності, що консолідується (Wilson, 2002, p. 31).

Ілюстрацією до вищенаведених даних, у той період, є дослідження Київського міжнародного інституту соціології в грудні 1997 року. Серед опитаних громадян України лише 56\% віднесли себе до українців, росіянами назвали себе $11 \%$, а 26\% відповіли, що вони одночасно належать до українського та російського етносів (Белецкий и Толпыго, 1998, с. 77).

Такий стан громадян, на думку автора, характеризується поняттям етнокультурної маргінальності. Під етнокультурною маргінальністю розуміють перебування особистості одночасно у двох або більше 
етнокультурних вимірах. Відповідно, етнічний маргінал - це певний соціальний тип внутрішньо нецілісної особистості, що стоїть на межі двох чи більше етнокультурних світів і не є органічно інтегрованою в жодний з них, а отже, перебуває в проміжному стані в системі етнічних відносин.

До особливостей етнокультурної маргінальності в Україні можна віднести:

1. Значне зростання проявів маргіналізму серед усіх етносів, які мешкають в Україні, що обумовлено системною трансформацією суспільства.

2. Поглиблення маргінальних тенденцій у зв'язку 3 активізацією міграційних процесів.

3. Рубіжний характер України (між Заходом і Сходом) породжує іï особливий етнокультурний статус як маргінальної держави, яка ще не відірвалася від Сходу, але й не примкнула до Заходу.

4. Наявність в Україні двох основних мов - української та російської 3 питання культурно-інформаційного перетворилося на політичне.

5. Відсутність загальнонаціональної державної еліти, яка змогла б консолідувати суспільство.

6. Відсутність виробленої стратегії національних інтересів, що негативно впливає на визначення національної ідентичності (Матета, 2007, c. 151).

Доцільно було б урахувати той факт, що процес державотворення в Україні розпочався раніше, ніж населення усвідомило себе громадянами незалежної держави. Цей факт, без сумніву, вплинув на формування бікультуралів та білінгвів. I це було б досить позитивним явищем, якби переважали ознаки титульної нації. Досить непогано, коли людина володіє двома чи трьома мовами або ж користується надбаннями кількох культур. Та коли переважає бажання користуватися російською мовою в державних установах, прихилятися перед російською чи західною культурою, тоді, на нашу думку, етнокультурний маргіналізм еволюціонує не в українську 
культуру, а в чужинську. А це, в свою чергу, ставить під загрозу існування самої держави (Матета, 2004, с. 11).

Таким чином, українська модель державотворення відбувалася за умов етнокультурної та політичної маргінальності значної частини еліти та населення, відсутності сформованого громадянського суспільства. Тому природно визначення національних інтересів відбувалося не шляхом їх визрівання в процесі консолідації української нації, а на державному рівні, i характеризувалося непослідовністю, хаотичністю, або як трактували в ті часи - різновекторністю.

Таке становище вплинуло і на дослідження категоріального апарату поняття «національні інтереси» серед вітчизняних науковців та політиків. Спостерігається значне розмаїття у їх поглядах на сутність поняття та класифікацію національних інтересів. Частина 3 них ототожнює дане поняття 3 державним інтересом, знаходячись під впливом західної політичної літератури, та безпосередньо школи «політичного реалізму» (Р. Ковалюк, М. Шульга, М. Юрій, Н. Москальова). Інші наголошують на тому, що основою національних інтересів в Україні мають бути соціально-економічні, культурні та інші потреби громадян (О. Воронянський, Г. Ситник). Третя група під національними інтересами воліє розуміти насамперед політикоправовий статус нації, збереження іiі ідентичності, зокрема мови, мистецтва, традиційної культури тощо (І. Кукса, С. Гончаров, А. Колодій).

Таким чином, різниця у поглядах вчених залежить від визначення ними суб'єкту національних інтересів. Для одних це держава, інших суспільство, ще інших нація. Відома дискусія серед українських вчених і 3 приводу дефініції поняття нація. У неї вкладається або етнічний зміст, або підкреслюється суто політичний, з’явився навіть термін «політична нація».

Це є не зовсім вірно, так як у самому визначенні нації існує політичний контекст. Так «Нація» - певна стадія соціоцивілізаційної зрілості етносу, на якій він виступає на арену політичного життя з чітко визначеними власними 
цілями і намірами з метою реалізації їх у політичній практиці (Антонюк, 2005, c. 213).

Вельми важливим для нашого дослідження, вважаємо аналіз правового поля існування українських національних інтересів. Адже без законодавчої основи формування, утвердження й забезпечення, національні інтереси залишатимуться лише намірами, а їх реалізація черговою декларацією.

Правову основу для формування, формулювання й реалізації національних інтересів України становлять Конституція України, Закон України «Про основи національної безпеки України» інші закони України, міжнародні договори, ратифіковані Верховною Радою України, а також видані на виконання законів інші нормативно-правові акти.

Становлення концепції національних інтересів України на законодавчому рівні розпочалося 3 прийняття Декларації про державний суверенітет України.

Фундаментальним національним інтересом Декларація проголосила «державний суверенітет України як верховенство, самостійність, повноту і неподільність влади Республіки в межах іiі території та незалежність і рівноправність у зовнішніх зносинах». Нею передбачалося здійснення Україною як суб’ єктом міжнародного права безпосередніх зносин 3 іншими державами: укладання 3 ними договорів, обмін дипломатичними, консульськими, торговельними представництвами, участь у діяльності міжнародних організацій у обсязі, необхідному для ефективного забезпечення національно-державного інтересу «у політичній, економічній, екологічній, інформаційній, науковій, технічній, культурній і спортивній сферах». Україна, зазначається в Декларації, виступає рівноправним учасником міжнародного спілкування, активно сприяє зміцненню загального миру i міжнародної безпеки, безпосередньо бере участь у загальноєвропейському процесі та в європейських структурах і «урочисто проголошує про свій намір стати в майбутньому постійно нейтральною державою, яка не бере участі у військових блоках і дотримується трьох 
неядерних принципів: не приймати, не виробляти i не набувати ядерної зброї» (Шемшученко ред., 2006, с. 188-189).

Конституція України використовує термін «національні інтереси» у 18 статті де йдеться про зовнішньополітичну діяльність України. У ній говориться: Зовнішньополітична діяльність України спрямована на забезпечення ii національних інтересів i безпеки шляхом підтримання мирного i взаємовигідного співробітництва 3 членами міжнародного співтовариства за загальновизнаними принципами і нормами міжнародного права (Конституція України. 2009, с. 6).

Закон України про національну безпеку України який діяв до 2018 року національні інтереси визначав як «життєво важливі матеріальні, інтелектуальні і духовні цінності Українського народу як носія суверенітету і єдиного джерела влади в Україні, визначальні потреби суспільства і держави, реалізація яких гарантує державний суверенітет України та іï прогресивний розвиток» (Законодавство України, 2003).

Чинний Закон України про національну безпеку України визначає національні інтереси як життєво важливі інтереси людини, суспільства i

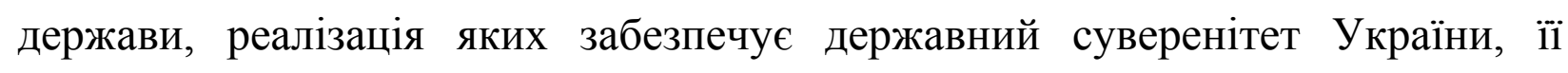
прогресивний демократичний розвиток, а також безпечні умови життєдіяльності і добробут їі громадян (Законодавство України, 2018).

3 цих визначень, ми також не бачимо єдиного суб’єкту національних інтересів. Якщо на початку незалежності це була виключно держава, потім вони асоціювалися 3 цінностями народу, а зараз їх кілька - це людина, суспільство і держава.

Проаналізувавши розуміння національних інтересів на законодавчому рівні, приходимо до висновку, що в Україні, взагалі, на законодавчому рівні національні інтереси не класифікуються, відсутня їх концепція та стратегія, на відміну, наприклад, від США. Український законодавець, як правило, дає визначення поняття «національний інтерес» та перелік пріоритетних національних інтересів. А враховуючи те, що в Законі України «Про Раду 
національної безпеки і оборони України», до компетенції РНБО відноситься визначення стратегічних національних інтересів України (Законодавство України, 1998), складається враження, що документи стосовно визначення національних інтересів України є певною мірою утаємничені.

Характеризуючи поняття національних інтересів, потрібно усвідомлювати, що інтерес взагалі - це об’єктивно зумовлений мотив діяльності окремої людини, соціальної спільноти, суспільства в цілому, спрямований на досягнення мети.

Якщо поняття національної безпеки виражає стан захищеності держави, їі громадян від різних загроз, то поняття національних інтересів зміст головних цінностей, цілей і прагнень суспільства й держави на конкретно-історичному етапі розвитку.

«Енциклопедія етнокультурознавства» визначає «національний інтерес» як «реальну причину дій нації і держави, спрямованих на своє виживання, функціонування і розвиток», або як «сукупність національних цілей і базових цінностей, які відіграють важливу роль у стратегії і тактиці в галузі національної безпеки» (Римаренко ред., 2001, с. 421).

Національні інтереси $є$ синтезом різноманітних інтересів певної національної спільноти. Індивідуальні та групові інтереси викристалізовуються, проходять витримку часом, узгоджуються та зводяться до загального, а потім на їх основі й формуються національні інтереси. Саме це загальне А. Колодій розглядає як інтерес до самозбереження, до реалізації свого соціально-політичного і культурного потенціалу, форма якого властива саме цій нації (до реалізації національної ідеї). Серцевиною національних інтересів є збереження і зміцнення національного суверенітету, що означає «повновладдя нації, оволодіння нею всіма можливостями розпоряджатися власною долею» (Колодій, 2008, с. 39). Тому національні інтереси не можуть зводитись лише до якихось соціально-економічних, культурних та інших потреб. Вони повинні виступати як органічний синтез, а не механічна сума приватних і корпоративних інтересів. 
Цілком погоджуємося 3 думкою О. Дзьобаня про те, що фактично національні інтереси повинні втілювати у собі зв’язок громадянського суспільства й держави, взаємодію між ними. Порушення цієї взаємодії, гегемонія одного з начал і слабкість, пригніченість іншого завдають збитку національним інтересам, деформуючи їх (Дзьобань, 2010, с. 128).

Отож, головним суб’єктом національних інтересів в Україні має бути певна соціокультурна спільнота, яка охоплює більшість населення України, усвідомлює свої інтереси та відповідальність, розуміє своє значення в історії, готова захищати свою ідентичність. Такою спільнотою, вочевидь, і $\epsilon$ українська нація.

Під національними інтересами, вважаємо за потрібне, розуміти сукупність загальних для нації інтересів і потреб, задоволення і захист яких є необхідною умовою іï існування як суб’єкта історії. У національних інтересах виражається потреба нації займати те місце у світовій спільноті, яке у повній мірі відповідає їі культурно-історичним і духовним традиціям, дозволяє максимально реалізувати ії потенціал.

А під поняттям «українська нація», варто розуміти як представників українського етносу, так i національних меншин, котрі $є$ громадянами України.

Висновки і перспективи подальших досліджень. Таким чином, розглядаючи категоріальний апарат поняття «національні інтереси», приходимо до висновку, що у зарубіжній літературі це поняття фактично асоціюється з геополітичними інтересами держави, представленням інтересів нації на міжнародному рівні. Такий стан справ є наслідком сформованості у цих країнах націй, громадянських суспільств, правових держав.

В Україні, яка протягом століть практично не мала традицій розвитку власної державності, категорія національних інтересів має інший зміст. Зокрема, сутність їх багато в чому визначається, в наш час, необхідністю вдосконалення процесу державотворення, закріплення власної державності, iіi 
самозбереження, формування української нації, патріотичного виховання громадян.

За умов перехідного стану, у якому перебуває наша країна, коли досі залишаються невирішеними багато 3 аспектів політичної й економічної трансформації, національні інтереси мають бути фундаментальною основою національної безпеки України.

Національні інтереси України, як підгрунтя безпечного існування нашої держави, мають бути не тільки проголошені у політичних програмах, а й закріплені у національному законодавстві, корелюватися 3 правовими цінностями демократичного суспільства.

Нація перебуває в небезпеці, коли існує загроза іiі національним інтересам - об'єктивним потребам матеріального та духовного існування як внутрішньоцілісного та самобутнього соціального утворення.

Визначення та реалізація національних інтересів являє собою складний, тривалий, багатоетапний процес, в якому беруть участь різні суб'єкти соціальної системи. Найкраще реалізація національних інтересів відбувається у взаємозв'язку нації, громадянського суспільства й держави. Порушення цієї взаємодії, гегемонія одного 3 начал і слабкість, пригніченість іншого завдають збитку національним інтересам, ставлячи під загрозу національну безпеку України.

\section{ЛІТЕРАТУРА}

1. Антонюк, О. 2005. Основи етнополітики: навч. посіб. для студ. вищих навч. закладів. Київ: МАУП.

2. Арон, Р., 2000. Мир і війна між націями. Переклад з французької В. Шовкун, 3. Борисюк та Г. Філіпчук. Київ: МП«Юніверс».

3. Белецкий М. и Толпыго А., 1998. Национально-культурные и идеологические ориентации населения Украины (по данным социологических опросов). Социс, 4, c. $76-78$.

4. Головаха, Є., 2016. Українське суспільство: вектори трансформації. [online] (Останнє оновлення 01 Грудень 2016) Доступно:URL: https://zbruc.eu/node/59471 [Дата звернення 05.10.2019].

5. Даль, Р., 1992. Введение в теорию демократии. Москва: Наука. 
6. Дзьобань, О. П., 2010. Національні інтереси як основа національної безпеки: світоглядно-методологічні аспекти. Вісник Академії правових наук України, 3, с. 124136.

7. Законодавство України, 1998. Закон України про Раду наџіональної безпеки $i$ оборони України. [online] Доступно: https://zakon.rada.gov.ua/laws/show/183/98$\%$ D0\%B2\%D1\%80 [Дата звернення 10.10.2019].

8. Законодавство України, 2003. Закон України про основи національної безпеки України. [online] Доступно: http://zakon2.rada.gov.ua/laws/show/964-15 [Дата звернення 10.10.2019].

9. Законодавство України, 2018. Закон України про наџіональну безпеку Украйни. [online] Доступно: https://zakon.rada.gov.ua/laws/show/2469-19 [Дата звернення 10.10.2019].

10. Кеннан, Дж., 2002. Дипломатия Второй мировой войны глазами американского посла в СССР Джорджа Кеннана. Перевод с английского Л. А. Игоревского, Ю. Д. Чупрова. Москва: Центрполиграф.

11. Колодій, А. 2008. Національний вимір суспільного буття. Львів: Астролябія.

12. Конститучія Украӥни. 2009. Харків: ТОВ «Одіссей».

13. Матета, О. А., 2004. Особливості етнокультурної маргінальності в Україні: теоретичний аспект. Людина і політика, 3, с. 9-13.

14. Матета, О.А., 2007. Політична та етнокультурна маргінальність у трансформаційних процесах пострадянської Украӥни. Кандидат політичних наук. Харківський національний університет імені В.Н. Каразіна.

15. Матета, О. А., 2018. Ціннісні виміри трансформації сучасного українського суспільства. Сучасне суспільство: політичні науки, соціологічні науки, культурологічні науки, 1 (15), с. 87-99.

16. Москальова, Н. П., 2016. Концепції національного інтересу в науковій літературі. Вісник Донецького національного університету. Політичні науки, 1, с. 29-32.

17. Римаренко, Ю. І. ред., 2001. Особа, нація, культура. В: Енциклопедія етнокультурознавства. Кн. 2: «Е-Н» Київ: Друкарня Державної академії керівних кадрів культури та мистецтв.

18. Ситник, Г. П., 2010. Концептуальні засади забезпечення національної безпеки України: навч. посіб.: у 3 ч. Державна політика та основи стратегічного планування забезпечення начіональної безпеки. Ч. 3. Київ: НАДУ.

19. Шемшученко, Ю. С. ред., 2006. Декларація про державний суверенітет України. Прийнята Верховною Радою Української РСР 16 липня 1990 р., В: Конституиії $i$ конституційні акти Украӥни: історія і сучасність. 2-ге вид. змінене і доп. Київ: Ін-т держави і права ім. В. М. Корецького НАН України. с. 188-192.

20. Huntington, S. 1996. The Clash of Civilizations and the Remaking of World Order. N.-Y.: Free Press.

21. Morgenthau Hans, J. 1982. In Defense of the National Interest. University Press of America.

22. Wilson, A., 2002. Elements of a Theory of Ukrainian Ethno-National Identities. Nations and Nationalism. 1. p. 31-54.

23. Wilson, W. 1970. College and State Educational, Literary and Political Papers (18751913). Vol. 2. New York: Columbia University Press. 


\section{Інформація про автора}

Матета Олексій Анатолійович - кандидат політичних наук, доцент, спеціаліст вищої категорії, викладач-методист Кременчуцького льотного коледжу Харківського національного університету внутрішніх справ; e-mail: mateta@ukr.net; ORCID: https://orcid.org/0000-0002-3087-9832

Стаття надійшла до редакції: 02.11.2019 р. $\quad$ Прийнята до друку: 22.11.2019 p. 